Originally published: Citizenship Studies, Vol. 25, No. 4 (2005)

\title{
Human rights culture: solidarity, diversity and the right to be different
}

Kate Nash

Department of Sociology,

Goldsmiths College,

University of London,

London SE14 6NW

+44(0)2079197734

k.nash@gold.ac.uk 
Goldsmiths Research Online. Human rights culture

\title{
Human rights culture: solidarity, diversity and the right to be different
}

\begin{abstract}
The concept of a human rights culture has been crucial to the incorporation of the European Convention of Human Rights into UK law. In this paper media and activist representations of human rights for lesbian, gay, bisexual and transgender human rights are considered as indicative of an emerging human rights culture, especially around the Civil Partnerships Act 2004. A typology of representations of rights is developed and discussed. It is concluded that insofar as there is an emerging human rights culture, it is one that is concerned above all with creating and maintaining civic relationships rather than with the assertion of individual liberty, and as inviting political compromise rather than a principled stance on universal human rights.
\end{abstract}

Keywords: lesbian, gay, bisexual and transgender rights; activists; media representations; law; UK Human Rights Act 
Goldsmiths Research Online. Human rights culture

\section{Human rights culture: solidarity, diversity and the right to be different}

\section{Introduction}

There has long been controversy over the consequences for democracy of introducing European human rights to the UK, in large part concerning the relative balance of powers and the effects of a written constitution (Bellamy 1999; Ryan 1991); see also The Political Quarterly special issue 'Human Rights in the UK' 68/2 1997). The idea of 'human rights culture' apparently offers a 'Third Way' between opponents and advocates of incorporation, suggesting the possibility of reconciling liberalism and communitarianism, 'rights' as law ultimately determined by the judiciary and 'rights' as institutionalised democratic demands achieved through parliamentary sovereignty. This paper focuses on media content as a vital, though neglected, aspect of the success of this solution. It considers media representations of human rights as they appeared in newspapers in relation to the 2004 Civil Partnerships Act (CPA), as the most significant human rights legislation in the UK following the incorporation of the European Convention of Human Rights (ECHR) in the 1998 Human Rights Act (HRA) (1). Media representations of human rights are not the only basis for a human rights culture, but they are crucial to it. In addition, the article also considers the views of lesbian, gay, bisexual and transgender (LGBT) rights-activists through interviews, and representations of rights in the LGBT press. Mainstream and activist representations are analysed as firstly, indicative of the emergence of a human rights culture; and 
Goldsmiths Research Online. Human rights culture

secondly, to determine what form a possibly emerging human rights culture might be taking.

In fact, as the analysis demonstrates, a clear cut distinction between media representations and activist commitments can not be sustained as use of the mainstream media has been an important tactic of LGBT organisations: activists are often quoted and interviewed in the mainstream media and some write for the liberal press, Stonewall has successfully placed 'human interest' stories in the media, Outrage! has mobilised primarily through a politics of the spectacular and so on. Moreover, with notable exceptions that will be discussed below, mainstream newspapers, the LGBT press and LGBT rights activists have converged over time around a broad consensus on the value of rights as supportive of relationships of democratic dialogue and compromise rather than as involving the assertion of individual or group identities and interests against the dominant majority. Media and activist representations of human rights in relation to the CPA do, to this extent, embody the ideal of communitarian human rights culture proposed by government and policy networks - except that 'human rights' are rarely represented as such but rather as 'rights' qualified in different ways. The article explores how 'rights talk' is framed in the media through a typology of representations of rights, analyses the convergence between mainstream media, LGBT media and LGBT rightsactivists' representations of rights, and details how this convergence is at the expense of a more radical version of individual freedom and the right to be different. A communitarian 'human rights culture' is one in which - for better 
Goldsmiths Research Online. Human rights culture

or worse - an ongoing negotiation of civic solidarity across differences is valued over universal principles of individual freedom.

\section{Human rights culture}

Although the European Court of Human Rights has, to date, never actually found against any European government with respect to the rights of samesex partnerships as such, there has been a general trend towards abolishing discrimination between same-sex and different-sex couples in Europe, strengthened by the European Parliament's recommendation in 2000 that national law throughout the Union should be changed to recognise the rights of individuals in same-sex partnerships as equal to those of married couples (Wintemute 2001). Moreover, there have been a number of cases of discrimination on the basis of sexuality that have been decided against the UK in the European Court of Human Rights (Wintemute 1995) and LGBT groups have long directed their efforts to ending discrimination in the UK towards the EU. HRA was widely understood, as a result, to herald the necessity of equalising rights to same- and different-sex partnerships in UK law. The CPA therefore represents the first extensive human rights legislation in the UK and offers an ideal opportunity for studying whether or not human rights culture is emerging, and whether it is developing in such a way as to fulfil the hopes of its champions.

The importance of human rights culture for the success of the incorporation of ECHR was, and continues to be, a topic of government pronouncements and documents produced by policy networks (J oint Committee on Human Rights 
Goldsmiths Research Online. Human rights culture

2003; Klug 2000; Parekh 2000; Watson 2002). As such, the ideal of the HRA is not just that the UK will become more closely connected to Europe by incorporating the ECHR, it is also that there should be a radical change in British political culture. For advocates of human rights culture, British society, which has tended to be seen as suspicious of rights as individualistic and undemocratic and as promoting an undue and undemocratic reliance on law, judges and lawyers (Conover, et al. 1991; Searing, et al. 2003), should welcome human rights values as the basis of a more democratic and more inclusive society. Attempting to assuage fears on the nationalist right, HRA is presented as safeguarding parliamentary democracy by bringing the ECHR into UK law. As HRA encodes very few absolute rights (unlawful killing, torture and slavery are prohibited absolutely, while the right to a fair trial is absolutely guaranteed), and in the vast majority of cases encourages the consideration of balance between individual rights and public interest (in respect of freedom of expression and association, respect for privacy and family life and so on), clashes between the executive and judiciary are expected to be rare. Moreover, in the more positive terms aimed at the progressive left, human rights are seen as perfectly suited to a multicultural society, offering the possibility of respect for diversity whilst at the same time promoting a communitarian solidarity around shared values to replace the exclusionary, and now decaying sense of 'national belonging' which has previously been so influential.

The aim of establishing a human rights culture is, therefore, not solely directed at the political and judicial establishment. It is not a public political 
Goldsmiths Research Online. Human rights culture

culture in the Rawlsian sense, which is that of officials engaged in making policy and deciding law. Nor is it a legal culture in the sense that legal scholars might understand. What is intended by advocates of human rights culture is rather a 'popular political culture', which draws citizens and elites together in terms of shared values. A human rights culture is one in which values of both solidarity and diversity are shared, in which individual freedom, and therefore minority rights, are respected, but in which democratic decisions arrived at by majority voting and taken with such considerations in mind are accepted as binding and legitimate. A human rights culture should bring elites and people together in a celebration of common values such that it is rarely necessary to subject democratic decisions to damaging judicial review, nor for citizens to take public authorities to court, because the basics of human rights are what guide public policy-making and legislation.

Rights for sexual minorities are an ideal topic for such a case study because they may potentially be 'framed' in many different ways. As Alan Ryan has pointed out, in the British legislation of the 1960s, concessions to homosexuals' were not conceived of in terms of rights at all; reform was argued for rather on the humanitarian grounds that banning homosexuality served no purpose, was generally unenforceable and disproportionately injured the few individuals who were unlucky enough to be caught (Ryan 1991: 419-20). Although rights for sexual minorities have an obvious resonance with arguments for individual freedom and equal rights to justice in liberal political theory, Ryan suggests that British political culture has made such arguments rather unlikely (in comparison with the United States); though he 
Goldsmiths Research Online. Human rights culture

also suggests that this may now be changing. British political culture has found 'rights' talk too individualist, preferring to trust in the informal social checks and balances of shame, reputation and gentlemanly honour in the social networks that have maintained elite institutions. Analysis of media and activist representations of rights for sexual minorities in the case of the CPA therefore provides a useful case study through which to enquire as to whether 'rights' are now becoming acceptable, even celebrated, in Britain. What do 'rights' mean? How are they understood in relation to other important values of political life?

\section{Researching human rights culture}

Although 'public opinion' is not to be understood as formed exclusively in the media, given the fairly technical nature of debates over rights, the media will undoubtedly play a very significant part in the formation of a human rights culture. Media representations of human rights can, therefore, be taken as indicative of an emerging human rights culture, though more research would be needed to find out how extensive and intensive it might be among the general population.

The CPA was the result of long political campaigning on the part of social movement organisations, especially the lesbian, gay, bisexual and transgender (LGBT) movement organisation Stonewall. In general terms, the CPA allows for the legal recognition of same-sex couples as having all the rights and responsibilities of married couples, though same-sex couples are denied the possibility of marrying in a religious ceremony. A Civil Partnerships Bill was introduced in 2003, following a three-month period of consultation, in which 
Goldsmiths Research Online. Human rights culture

Stonewall was again closely involved. The analysis of the media on which this research was based was actually carried out over a much longer time frame, from 1993. This is because all those involved in campaigns for LGBT rights I interviewed were convinced that equalising the age of consent for gay men had been absolutely crucial to the relative acceptance of 'gay rights' subsequently, and therefore to the possibility of the CPA (2). The analysis began, then, with the campaign to equalise the age of consent when permission was granted to take a case to the European Court of Human Rights for breach of rights to privacy on April 5th 1993 (by Wilde, Parry and Greenhaulgh); followed various test cases in the European Court of Human Rights, Bills, and finally the Parliament Act that equalised the age of consent in 2000, as well as a Private Member's Bill on same sex marriage in 2002, the period of consultation and readings of the $\mathrm{CP}$ Bill, to the passing of the CPA in November 2004. (3)

The media analysis was limited to newspapers for practical reasons. Political authority and policy-making is increasingly closely linked to popular culture (see Street 1997), and the activists I interviewed were convinced that characters in soap operas, the coverage of the private lives of celebrities, reality TV and so on had been very important in shaping public opinion on these topics. In this sense, newspaper coverage is no more than an indicator of media coverage in general, which is no more than an indicator of human rights culture as such. However, the selection of newspaper coverage was justified insofar as it was necessary to study mediated sites in which the relationship between human rights and LGBT rights would be directly addressed. In addition, broadsheets and tabloids alike self-consciously take 
Goldsmiths Research Online. Human rights culture

on the responsibility to construct a public sphere aimed at influencing legislation and policy-making. However well or badly they may fulfil that role, newspapers present themselves as providing both the setting and the symbolic resources for the formation of a popular political culture.

Newspapers fall into two broad types on the topic of rights for sexual minorities, as they no doubt do on other issues concerning what are constructed as absolute moral values. The conservative liberal press, in favour of the status quo, is represented in this study by The Daily Telegraph and The Sunday Telegraph, The Daily Mail and The Mail on Sunday, and The Sun. Progressive liberal newspapers, in favour of full equality of rights and respect for sexual minorities, are represented in this study by The Guardian and The Observer. The conservative liberal press has a readership that is many times greater than that of the progressive liberal press (see the Audit Bureau of Circulations).

As well as the analysis of mainstream media, the research also involved interviews with members of Stonewall, Outrage!, and the human rights organisation Liberty, all of which were involved in these campaigns for LGBT rights, as well as analyses of press releases and internet sites produced by these organisations. Finally, representations of human rights for sexual minorities were analysed in the The Pink Paper, the only LGBT paper in existence for the whole period of the study, a freesheet that presents itself as reporting and mobilising around cultural and political issues for 'the [LGBT] community'. 
Goldsmiths Research Online. Human rights culture

\section{Media Representations of Human Rights}

In fact, the term 'human rights' appeared very rarely in mainstream newspaper coverage of rights for sexual minorities. Almost all the uses of human rights' in the mainstream are direct or indirect quotations from the leaders of activist organizations. In contrast, human rights' was used much more frequently in The Pink Paper, no doubt to emphasise the importance and urgency of legislating in this area. The term 'rights', was, however, frequently used in the mainstream, and this use can be categorised in terms of six basic types. 'Rights' can be: strategic; advancing rational progress; universal principles, intrinsically linked with responsibilities; dialogic; and legal.

\section{Strategic rights}

Throughout the period covered by the analysis, the conservative liberal press used the term 'gay rights' as practically synonymous with 'the strategic use of rights for other ends'. However, both broadsheets and tabloids underwent quite a dramatic change of tone over the period. It would be difficult to exaggerate the drama of metaphysical struggle between good and evil staged by the conservative liberal press over the campaign to equalise the age of consent, not just in terms of a homophobic abhorrence of the idea of gay sex, but also in relation to the fundamental freedoms of British democratic institutions. 'Objectivity' over the equalization of consent was achieved in the conservative liberal broadsheets by some, very few, articles putting the case for equalisation to 'balance' the great majority putting the case against it, while there were no articles for equalisation in the conservative tabloids and very little 'neutral' reporting around it. Use of the term, 'gay rights' did not 
Goldsmiths Research Online. Human rights culture

vary significantly in meaning over this period, but it did become much less frequent, opposition to civil partnerships was not nearly as strident as to equalising the age of consent, it was balanced by other views and more neutral reporting, and in the later campaign 'rights' were increasingly linked to 'responsibilities' and described as legal rights' as well as 'gay rights'. 'Gay rights' continued to denote 'strategic rights' as fundamentally undemocratic, aiming to gain special consideration for minorities by making use of secret and underhand techniques to avoid the democratic process which went against the will of ordinary, respectable people. But due in part to newspapers' response to public opinion, representations of 'rights' became more diverse in the conservative liberal press in relation to campaigns for rights for sexual minorities during this period.

There were two main themes to the representation of gay rights as 'strategic rights' in the conservative liberal press during these campaigns. Firstly 'gay rights' were strategic because they involved a European take-over of British parliamentary democracy. In the conservative liberal press, the UK government was invariably represented as 'forced' or 'compelled' to bring legislation in line with European definitions of human rights and, therefore as acting strategically with regard to rights. The legislation equalising the age of consent in particular was represented as at odds with democracy, and this was confirmed by the use of the Parliament Act to equalise the age of consent despite the House of Lords' rejection of the proposed legislation for the third time. This theme practically disappeared in relation to the CPA. Although the conservative liberal press remained generally hostile to the European Union, 
Goldsmiths Research Online. Human rights culture

the incorporation of human rights into national law removed the force of the charge that Europe was undermining of British sovereignty in this particular case. Secondly, 'gay rights' were described as effective because they appeal to the elite, sometimes described as 'the metropolitan elite', which is unduly influenced by minority pressure groups, made to feel ashamed in the face of 'political correctness'. 'Strategic rights' are suspect because they go behind the backs' of the British public, in a kind of conspiracy to make acceptable that which people would not ordinarily accept in any other terms.

The change of tone of the conservative liberal press over this period was due in part to the way in which the newspapers interpreted opinion polls that they reported in their pages. With respect to equalising the age of consent, both progressive and conservative liberal newspapers reported that there was a small majority against the legislation and that ultimately the government decided against that opinion to bring the country in line with the judgement of the European Court of Human Rights. The Civil Partnerships Bill was represented differently, however, again in both progressive and conservative liberal press, as generally supported by the majority, and this reading of public opinion had consequences for the style of reporting on the issue.

Of course, equalising the age of consent and the CPA also differ significantly as issues: the involvement of minors in the first might be expected to engage the paternalist conservative press and, as we have noted, the pressure of the European Union was not as prominent in the case of the CPA as it was over the equalisation of the age of consent. However, a number of articles on the 
Goldsmiths Research Online. Human rights culture

threat posed by civil partnerships to normal, natural marriage (eg The Meaning of Marriage' The Daily Telegraph 1.7.03; Melanie Phillips The Murder of Marriage' The Daily Mail 26.11.2003) suggest an obvious conservative position, and one which would have been more consistent with their previous coverage of 'gay rights', beginning from the premise that it is not homosexuals who will be most affected by the legislation, but the heterosexual majority duped and weakened by 'political correctness'. Like the Conservative Party itself, whose explicit repositioning of its values as favourable to 'social liberalism' actually began with J ohn Major's support for the equalisation of consent and became increasingly prominent throughout the leadership changes of 90 s and 00s, the conservative liberal press responded to public opinion that it had apparently not been able to influence on issues such as acceptance of same-sex relationships. The representation of rights as 'strategic', so dismissive of the issues at stake, therefore became much less plausible and was relegated to a very minor theme in the conservative liberal media treatment of LGBT rights.

\section{$\underline{\text { Rights as progress }}$}

The representation of 'rights as progress' is made in liberal progressive newspapers and the LGBT press, where it is quite often deployed alongside representations of rights as linked to linked to responsibilities, as dialogic and as legal. The assumption that underpins this representation, that we are all, of course, in favour of rights for sexual minorities, is a mirror image of conservative liberal fears that 'gay rights' have an unstoppable momentum because of their hold on the psyche of the elite and because Britain is in thrall 
to Europe. Indeed, this representation is strongly linked to a pro-European stance: Europe is seen as 'enhancing our freedoms' through the extension of rights for sexual minorities (The Guardian editorial 4.7.03).

There is a limited sense in which progress in rights means only that social mores have changed and that rights must keep up with such changes, as in the following quote from Ben Summerskill, then chief executive of Stonewall, on the Vatican's campaign against gay marriages as evil, 'It is a last desperate bid to cling on to the C19th from an organisation which has failed to admit that we are in the C21st' (quoted in Rebecca Allison 'Pope calls for halt to evil gay marriages' The Guardian 1.8.03). However, in part in opposition to 'the Daily Mail reader' but also against 'gay rights activists' and others who are not reasonable, the progressive liberal press also represents rights as rational in a more militant fashion. An extreme example, in response to the protests outside parliament following the reduction of the age of consent for gay men to 18 , rather than to 16 , which would have made it equal to heterosexuals, is the commentary in The Guardian which appeals to the rational reader of the paper over the 'fringe feminism, fringe ethnic campaigning, gay rights and the interests of particular groups like teachers [who] stand up and delight immediate participants as it turns the middling public away and off. In order to debate, understand and influence the political process on gay rights, errors and misconceptions but also inappropriate emotions like self-pity and rage must be cleared away. There are no metaphysical battles of good against evil to be fought here: 'All sense, all equity, all good manners and tolerance are for 
Goldsmiths Research Online. Human rights culture

equality, so let's get on with it' (Edward Pearce 'Public Tantrum versus

Friendly Persuasion' The Guardian 26.2.94).

The cumulative effect of endorsements of rights as progress is to suggest that there is a direction to history, out of the darkness of prejudice and ignorance, towards modern equality and freedom, such that an increase in rights for sexual minorities is both to be expected and right, that it is also emblematic of the progress of social relationships as such. Rights are modernising: there is no alternative. This representation also reflects the fears of the conservative liberal press in being similarly undemocratic, perhaps even anti-democratic, since it is assumed that opposition to rights will simply be erased: there is only one reasonable outcome where the extension of rights is represented as progress.

\section{$\underline{\text { Rights as universal principles }}$}

'Rights' as principled are based on the argument, never actually rehearsed in the media, that human rights are absolute and universal, that they exist whether or not they are enshrined in law, and that they can not be traded or compromised. In the case of rights for sexual minorities, statements of human rights principles indicate that individuals are persecuted because of lack of rights, and demand equal rights for sexual minorities as a priority for a democratic society.

An explicit representation of principled human rights of this kind is rare in both the mainstream press and The Pink Paper and when it does appear it is 
Goldsmiths Research Online. Human rights culture

often linked to Peter Tatchell's name and to Outrage!, which he helped set up and in which he has been involved since 1990. Tatchell also writes extensively on human rights from a principled position on his own website (www.petertatchell.net) and regularly refers to human rights in letters, interviews and articles in mainstream and minority newspapers.

The expression of principled human rights exemplified in Peter Tatchell's pronouncements and activities has attracted a good deal of attention. It is often seen as antithetical to winning human rights for sexual minorities in the mainstream media and, therefore, as a consequence, in The Pink Paper too. For the conservative liberal press, principled rights become unprincipled strategy because there are no shared values: Tatchell is reviled as a 'gay rights activist' who will admit of no compromise and who has no respect for the values of the democratic majority. The progressive liberal press and the LGBT newspapers are also hostile to the expression of Tatchell's intransigent principles when they appear to be working against progress towards rights for sexual minorities; for example, where they are connected to direct political action that is seen as unpopular. Otherwise his understanding of principled rights receive fairly neutral coverage in The Guardian and The Observer and, in addition to fairly neutral coverage, The Pink Paper also occasionally represents Tatchell's tactics of direct action as Tatchell himself represents them, as complementary to, rather than destructive of, Stonewall's attempts to use the mainstream political process to achieve equality for sexual minorities. 
Goldsmiths Research Online. Human rights culture

However, there is an important exception to the pragmatism of the progressive liberal press. Tatchell rejected the Civil Partnerships Bill in the name of principled human rights because it discriminated against heterosexuals, whether unmarried couples, friends or relatives, who were in similarly supportive relationships that were not recognised in the proposed law. The Guardian leader congratulated LGBT activists - effectively Peter Tatchell - using the term 'gay human rights activist' for the first time, rather than 'gay rights activist', for their comradely solidarity (Leading article 'Victory for Gay Couples' The Guardian 1.7.03). This is significant because of the way in which 'human rights' are universalised here, both in Tatchell's intervention and in the name, 'gay human rights activist' compared to 'gay rights activist'. Progressive liberalism is suspicious of statements or actions based on principles insofar as they may put the progress of the very principles themselves in jeopardy, but where they are demonstrably universal rather than demands for 'special rights' for minorities they are worthy of praise and respect, however politically naive.

There is a vast literature on how the specification of 'the universal' is ideological, obscuring or over-extending 'the particular' rather than transcending concrete limitations (see, for example, Benhabib, et al. 1995; Young 1990). Media representations of Tatchell's use of the language of principled universal rights fit this understanding of 'the universal' as always already particular. In this case, what is evident is how universal and 'normal' are intertwined in invocations of 'universal rights'. Tatchell's attempts to claim universal rights for same-sex partnerships is suspect because it appears 
Goldsmiths Research Online. Human rights culture

as a strategy for demanding 'special rights'. It is only once he claims 'universal' rights for heterosexuals that his demands are given credit for their basis in universal principle. Although in this case claims for 'universal rights' actually enabled consideration of those (heterosexuals) who were neglected in the law (intentionally, in fact, in order to separate civil partnerships from the contentious issue of 'gay marriage'), what is more important here is the way in which representations of universal rights, understood as a strategy for achieving 'special rights' served to close off the inclusion of different points of view in the press, including the progressive liberal press. The figure of Tatchell is treated with suspicion, partly because of his involvement in direct action, but partly because the representation of universal principles of human rights apparently only make sense in relation to the 'normal' majority.

\section{Rights with responsibilities}

Balancing rights and responsibilities have been a feature of New Labour's introduction of human rights law into the UK. On announcing the Civil Partnerships Bill on the J une 30th 2003J acqui Smith, the Minister responsible, emphasised the link between rights and responsibilities and this was widely reported in both conservative and progressive liberal press: lesbian and gay couples were gaining responsibilities for the care of long-term partners as well as rights. The CPA is portrayed, according to this interpretation, as more concerned with organising relationships in the private domestic sphere than with carving out a domain of individual freedom. However, although the construction of 'rights with responsibilities' certainly 
Goldsmiths Research Online. Human rights culture

appealed to both progressive and conservative liberal press, linking rights and responsibilities need not necessarily be conservative.

As we have noted, the use of 'gay rights' as strategic continued throughout the period studied in conservative liberal newspapers, but coverage of views over civil partnerships explicitly made the point that these rights also brought responsibilities.

One of the main ways of representing rights and responsibilities as intrinsically linked, in both the conservative and the progressive liberal press, was in terms of human-interest stories around the Bill. Even during the period at which the conservative liberal press was most hostile to 'gay rights' and 'gay rights activists', human-interest stories were run alongside articles expressing dismay at strategic rights, enabling sympathy - albeit often intertwined with suspicion and no doubt prurience - for those who suffer as homosexuals' (eg see Sharon Churcher 'Dark Side of the Man Who Sold Women the American Dream' The Daily Mail 21.2.1998). Although 'humaninterest' stories were patronising, they did enable a wider consideration of who was affected by the Bill and how than would surely have been possible given conservative liberal hostility to 'gay rights' and no doubt they contributed to a change of emphasis in conservative liberal representations of rights. In relation to civil partnerships, many of the human-interest stories focussed on couples that Stonewall had encouraged to come forward (interview with Stonewall's Communications Officer, Helen Marsh 15.11.03), showing how partners had already been taking responsibility for each other over long periods of time. 
From a more radical point of view, however, the linking of rights and responsibilities in the CPA and in media representations of lesbian and gay couples was normalising, disciplinary and heterosexist. Although the CPA distinguishes between heterosexual and homosexual couples, what is more significant from the perspective of those who see the linking of rights and responsibilities in Third Way politics as an extension of disciplinary liberal governmentality is the way in which it expands the norm of the responsible self (Rose 1999). Those households which fall outside the expanded norm are those that are relatively unregulated by comparison, heterosexual, homosexual or non-sexual, in which people have not taken on normative responsibilities in law for themselves in relation to each other. As Davina Cooper puts it, legislation for civil partnerships 'shift[s] the boundary so that it runs through both gay and heterosexual communities, recognising...the mature and immature, the ruly and unruly, responsible and irresponsible in both' (Cooper 2004: 103). In addition, the disciplinary distinction between responsible and irresponsible may be seen as heterosexist insofar as it grants rights to members of households organised around a couple that is closely modelled on the 'original' heterosexual couple of 'man and wife', 'mother and father'. Whilst this is now extended to homosexual couples who conform fairly closely to such a model, it excludes a range of possibilities of relating to others sexually, emotionally and materially in households that are not organised in this way, potentially contributing to social injustice, lack of respect and persecution for those who follow marginalised ways of life.

Institutionalisation of rights and responsibilities need not necessarily contribute to what we might call 'substantive normalisation', nor to 
homophobia. For example, Peter Tatchell has proposed a model of what he calls 'civil commitments', a 'menu' of rights and responsibilities from which anyone - co-habiting or not, heterosexual, bisexual or homosexual, in a sexual or non-sexual relationship - might choose in order to formalise long-term relationships of care ('Civil Commitment Pact' www.petertatchellnet/ downloaded 26.2.04). Such a law would facilitate a range of relationships of care, multi-partner and/ or multi-site, which could explode the expectations of 'normal' family life. Insofar as such a law would depend on state regulation that would operate in conjunction with discourses of welfare and social security, it would undoubtedly contribute to the normalisation of a self who takes responsibility for themselves and for others. The critique of liberal governmentality, however, has anarchism as its implicit normative commitment, and law and regulation necessarily produces disciplinary effects. Tatchell's contractual model of civil commitments, which avoids creating or reinforcing a substantive norm in personal relationships, would seem to minimise such effects, and certainly to avoid heterosexism, facilitating respect for a diversity of ways of life.

Although Tatchell is far from an obscure figure in the media, and indeed his proposals were mentioned in both the conservative and progressive press, they were nowhere seriously considered. Although 'diversity' was enabled insofar as homosexual and heterosexual couples came, over time, to be considered, broadly, as equally legitimate in representations of rights and responsibilities, there was very little consideration of the limits of 'all affected' by the legislation, and no consideration at all of alternatives that might 
Goldsmiths Research Online. Human rights culture

include those for whom sexual, emotional and material responsibilities are not organised around an adult couple.

\section{Dialogic rights}

Dialogic rights, in contrast to principled rights, were represented as moderate and reasonable in the mainstream media and often associated with Stonewall. Dialogic rights are both strategic and principled; using strategy to safeguard principle but willing to compromise in order to achieve it. The dialogic representation of rights is no less a style of engagement than any other. It is more reasonable than the principled understanding insofar as it invites discussion and compromise, but it is not more rational in the Habermasian sense of a 'discourse ethics' generating universally valid norms. Dialogic rights have been developed by LGBT activists who work with mainstream institutions to bring about incremental change in the law and public acceptance of sexual minorities. They are, as a result, much more sensitive to, and oriented towards, achieving human rights for minorities through the democratic agreement of the majority.

There are a number of examples of dialogic rights both in the mainstream and minority press. There is a difference within the category of 'dialogic rights', between dialogue over whether rights are a suitable language within which to frame a particular issue group or event - dialogue about rights; and dialogue over which rights are most suitable once it has been decided that they are applicable - dialogue for rights. Once the journalist has established that she is motivated by the proper emotions, 'not anger, but remembered sadness, continued worry', Angela Mason is credited with using dialogic rights in both 
Goldsmiths Research Online. Human rights culture

senses in an interview she conducted with The Observer in 2000, when she was Director of Stonewall, a few days after the announcement of the second Sexual Offences Bill which eventually became law, equalising the age of consent for homosexuals and heterosexuals ('Euan Ferguson meets...Angela Mason' The Observer 13.2.2000). In the first case, dialogue about rights, she states that the public need protection from sexual offence, so that a language of equal rights to privacy has limits when it comes up against other important considerations, in this case those of conflicting moral values and where the public/ private distinction should be drawn. This is precisely the language of relative human rights in the HRA and it is implicitly directed against statements, covered in all major newspapers, by Peter Tatchell representing Outrage! for whom this had been a long-standing campaign, that equal sexual rights for gay men would mean the culturally and historically significant liberty to have sex in places currently designated public. In the second case, dialogue for rights, Mason argues for equality of the age of consent, suggesting that there has been a shift in ethical values so that 'young people...don't derive their moral values from the Establishment any more, the church, or Westminster, or whatever but have a sense of individual morality'. Equal rights to freedom for homosexual and heterosexual teenagers is not be feared because young people are moral and take responsibility for their own life decisions.

The Stonewall approach to dialogic human rights has also become quite dominant in the LGBT media. Over the period of the study The Pink Paper became much closer to Stonewall's approach to the struggle for LGBT rights 
Goldsmiths Research Online. Human rights culture

than to Outrage!'s. In 2000, for example, the paper ran a discussion of the age of consent in an edition celebrating the Sexual Offences Act in which the focus was at least as much on responsibility as rights, rehearsing arguments that a lower age of consent could see a growth in Sexually Transmitted Diseases and an increase in young people's exploitation by the pornography industry. The point was, of course, not to deny the justice of equality, but the tone of the article was that of a sincere consideration of arguments that might have been expected to come from conservative liberals, to question the limits of a language of rights with respect to other social concerns ('Legal at last. But can we cope?' The Pink Paper 31.10.2000).

Dialogic rights are a style of presentation; they do not necessarily require an actual exchange of views over rights except insofar as, like other styles of rights claims, they are participating in ongoing debates in the political public sphere. It seems likely, however, that in comparison with other types of rights claims, they do encourage such exchanges. LGBT activists who understand rights as dialogic take the view that they offer the best possibility of actually creating dialogue over rights. Angela Mason, for example, who successfully applied for Stonewall to gain charitable status as a human rights organisation when she was Director there, is of the view that the language of human rights offers real possibilities for dialogue across the NGO and voluntary sector (interview 30.1.04). For example, Stonewall's 'Citizenship 21' scheme has awarded funds to small projects run by a range of groups, including Muslim, J ewish and other local communities in inner cities and in the countryside. Dialogic rights may offer the means of achieving a movement of human rights 
Goldsmiths Research Online. Human rights culture

across diverse, and marginal, constituencies who would otherwise find it difficult to work together, as well as convincing the mainstream of the acceptability of human rights for minorities.

\section{Legal rights}

Apart from the other uses of rights we have looked at, the most common way of representing rights was as legal rights'. 'Legal rights' were especially prominent in both progressive and conservative liberal press in relation to the proposed legislation of the Civil Partnerships Bill, and before that in relation to Lord Lester's Private Members Bill on same-sex marriages. 'Legal rights' has connotations of 'acceptable' or at least 'accepted', presumably because, unless there is political protest against a particular law, it takes on the legitimacy of the law - or, it might be argued more plausibly in cases like the Sexual Offences Act which were widely seen as unpopular, deference towards it. In fact rights set out as Bills have yet to become law, and so 'legal rights' works in this context to make the law acceptable before it has even been made. 'Legal' is, therefore, more than the simple description of 'rights' that it appears to be: it is a description that adds the perceived legitimacy of the law and of established institutions, and therefore also value to what is, as we have seen, the highly contested term 'rights'.

\section{Conclusion}

By the end of the period that began in 1993 with a test case for the equalisation of the age of consent being granted permission to be heard in the European Court of Human Rights and that ended with the CPA 2004, rights 
Goldsmiths Research Online. Human rights culture

for sexual minorities had come to be valued across the range of conservative and progressive liberal media with which we have been concerned here. In particular, rights balanced with responsibilities, dialogic rights that allow for discussion and compromise, and legal' rights were valued. In contrast, arguments for rights as fundamental to individual freedom, or in terms of the equality of radically different ways of life, were virtually ignored. Perhaps somewhat surprisingly, there appear to have been no serious differences in this respect between the mainstream and the LGBT press, at least as represented by the most popular longstanding newspaper of 'the community', The Pink Paper. In terms of establishing a human rights culture, then, the evidence suggests that the media is contributing to a political culture of respect for rights insofar as rights are understood as concerned with relationships, both personal and public, and as open to compromise rather than with the assertion of the individual against the majority.

To this extent, newspaper coverage of debates leading up to the CPA may be seen as indicative of the emergence of a particular form of rights culture, a 'communitarian rights culture' valuing the attempt to reach and sustain agreement over conflict and divergence in understandings of social relationships. In some respects this is an artefact of the case study, which is concerned with what Habermas would call the substantive rights that are the outcome of democracy rather than with the fundamental rights that are its basis (Habermas 1996). On the other hand, however, there is no legal necessity for an understanding of rights for sexual minorities in terms of 'rights and responsibilities', 'dialogic rights' and legal rights'. On the 
Goldsmiths Research Online. Human rights culture

contrary: Articles 8 and 12 of the HRA - the most relevant for the CPA along with Article 14 proscribing discrimination in the rights covered by the Act stipulate that 'everyone has the right to respect for his (sic) private and family life' and 'men and women of marriageable age have the right to marry and to found a family'. Although these rights must be balanced against public interest according to the HRA, there is no legal reason why they should not have been more aggressively claimed in terms of fundamental individual freedom and the right to self-expression. As we have seen, however, principled claims for sexual minorities as fundamental and radical proposals for diversity had no political credibility in the mainstream media.

The case study therefore indicates that insofar as there is an emerging human rights culture in Britain, it is one that continues to find the idea of fundamental rights to individual freedom distasteful, at least for minorities who have historically been treated with suspicion, disgust and hatred. Instead the communitarian values of dialogue, compromise and respect for the law are being worked out in terms of a distinctive form of 'rights-talk'. Whether for good or evil, the case study suggests that, although rights are becoming increasingly highly valued in the UK, they continue to be understood in British political culture as granted by the sovereign and upheld by the people rather than as belonging to individuals whose freedom and equality in diversity must be respected and maintained, if necessary against the dominant majority and the will of the executive. 
Goldsmiths Research Online. Human rights culture

\section{$\underline{\text { Acknowledgements }}$}

Thanks to Suki Ali, Kirsten Campbell, Anne-Marie Fortier, Clare Hemmings, Paul Stenner and Neil Washbourne for comments on a previous draft of this article and for discussion of the research. (See also Notes 1 and 2 below.)

\section{$\underline{\text { Notes }}$}

1. The significance of the CPA (and also the Gender Recognition Act 2004, which unfortunately there was not room to cover here) was suggested by an advisory group set up to make recommendations for a longer-term research project, of which this study is a part. It consisted of Raza Husain, human rights lawyer at Matrix Chambers, David Bausor, legal advisor at the Lewisham Law Centre, J anet Hague, campaign director at Amnesty International UK, and Mark Littlewood, campaigns director at Liberty. I would like to thank them for all their help. I would also like to thank Professor Francesca Klug and Clare O'Brien of the Human Rights Centre at the LSE for preliminary discussion of the research. It goes without saying that responsibility for the research and its conclusions rests entirely with the author.

2. The interviews were carried out with Helen Marsh, the communications officer of Stonewall, and Angela Mason, Stonewall's director 1999-2003; David Allison, a founder member of Outrage!; Mark Littlewood, communications officer and J ames Welch, legal director of Liberty, and J ohn Wadham, director of Liberty 1995-2003. I would like to thank them for taking time out of their busy schedules to contribute to the research. 
Goldsmiths Research Online. Human rights culture

3. The analysis was carried out on representations of human rights around significant dates in relation to the Sexual Offences Act (SOA) 2000 and the CPA 2004; in each case, analysis of the newspapers was made five working days either side of significant dates. In the case of the SOA, these included two test cases in the European Court, that of Wilde, Parry and Greenhaulgh in 1993, which was granted permission to proceed, but which didn't actually go to court, and that of Sutherland and Morris v UK 1996; the readings of Edwina Currie's amendment to the Criminal J ustice Bill 1994 and Anne Keen's amendment to Crime and Disorder Bill 1998; and readings of the Sexual Offences Bill as it made its way through both Houses, to the Parliament Act in 2000. In the case of the CPA, the analysis began with Lord Lester's Private Members Bill in 2002, included the whole of the three-month consultation period before the $\mathrm{CP}$ Bill was announced, readings of $\mathrm{CP}$ Bills in the House of Commons and the House of Lords, to the Royal Assent in November 2004.

\section{WORDS 7,800}

\section{$\underline{\text { References }}$}

Bellamy, R. 1999 Liberalism and Pluralism: towards a politics of compromise, London: Routledge.

Benhabib, S., Butler, J., Cornell, D. and Fraser, N. 1995 Feminist Contentions: A Philosophical Exchange, London: Routledge. 
Goldsmiths Research Online. Human rights culture

Conover, P. J., Searing, D. and Crewe, I. 1991 'The Nature of Citizenship in the United States and Great Britain: Empirical Comments on Theoretical Themes', J ournal of Politics 53(3).

Cooper, D. 2004 Challenging Diversity: Rethinking Equality and the Value of Difference, Cambridge: Cambridge University Press.

Habermas, J 1996 Beyond Facts and Norms: Contributions to a Discourse Theory of Law and Democracy, Cambridge: Polity.

Joint Committee on Human Rights 2003 'The Case for a Human Rights Commission', London: House of Lords and House of Commons.

Klug, F. 2000 Values for a Godless Age: the Story of the UK's New Bill of Rights, London: Penguin.

Parekh, B. 2000 The Future of Multi-Ethnic Britain: Report of the Committee on the Future of Multi-Ethnic Britain, London: Profile.

Rose, N. 1999 'Inventiveness in politics', Economy and Society 28(3).

Ryan, A. 1991 'The British, the Americans, and rights', in M. J . Lacey and K. Haakonssen (eds) A Culture of Rights: the Bill of Rights in philosophy, politics, and law 1791 and 1991, Cambridge: Cambridge University Press.

Searing, D., Conover, P. J . and Crewe, I. 2003 'Citizenship in the Age of Liberalism', Parliamentary Affairs 56.

Street, J . 1997 Politics and Popular Culture, Cambridge: Polity.

Watson, J 2002 'Something for Everyone: the impact of the Human Rights Act and the need for a Human Rights Commission', London: The British Institute of Human Rights. 
Goldsmiths Research Online. Human rights culture

Wintemute, R. 1995 Sexual Orientation and Human Rights: the United States Constitution, the European Convention and the Canadian Charter, Oxford: Clarendon Press.

- 2001 'Strasbourg to the Rescue? Same-Sex Partners under the European Convention', in R. Wintemute and M. Andanaes (eds) Legal Recognition of Same-Sex Partnerships, Oxford: Hart.

Young, I. M. 1990 J ustice and the Politics of Difference, Princeton, New J ersey: Princeton University Press.

The Political Quarterly special issue 'Human Rights in the UK' 68/2 1997 